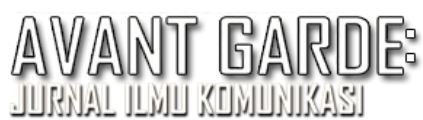

9-155N: 2333-4318

$3-155 N_{3} 235 \%-151 \%$

\title{
Muamalat Bank Mosque Management Training 'The Best Social Marketing"' Viewed From Public Relations Theories
}

\author{
Juan Malik Frederick Turpyn, Anggaraksa Adwitiya Arrazy \\ Universitas Al-Azhar Indonesia \\ Sisingamaraja Street, Kebayoran Baru, DKI Jakarta \\ juan.turpyn@gmail.com, anggaraksaadwitiya@gmail.com
}

Submitted: 31 Agustus 2021, Revised: 13 September 2021, Accepted: 20 Oktober 2021

\begin{abstract}
The development of Information and Communication Technology makes it easier for humans to carry out their daily activities. Every element of society can certainly move to create a better human life. One of them is Bank Muamalat. This company helps mosques in Java and Sumatra in carrying out mosque management activities. This study also aims to analyze and examine descriptively the management of the Muamalat Bank mosque, which was awarded as "The Best Social Marketing" which was reviewed through Public Relations theories. The research that method will be used is qualitative approach. Also, researchers choose a method with document studies so that the data taken is in accordance with existing reality. The result of this research is that Bank Muamalat Mosque management training has tried to utilize technology through pieces of training held by Bank Muamalat itself in collaboration with the National Amil Zakat Agency (BAZNAS) to train mosque management to develop in the digital era as now.
\end{abstract}

Keywords: Muamalat, mosque management, training, public relations theories

\section{Pelatihan Pengelolaan Masjid Bank Muamalat ' 'The Best Social Marketing”' dari Sudut Pandang Teori Public Relations}

\begin{abstract}
Abstrak
Perkembangan Teknologi Informasi dan Komunikasi memudahkan manusia dalam melakukan aktivitas seharihari. Setiap elemen masyarakat tentunya dapat bergerak untuk menciptakan kehidupan manusia yang lebih baik. Salah satunya adalah Bank Muamalat. Perusahaan ini membantu masjid-masjid di Jawa dan Sumatera dalam melaksanakan kegiatan pengelolaan masjid. Selain itu, Bank Muamalat juga membuat aplikasi bernama SmartMasjid untuk memudahkan operasional pengelolaan masjid sehari-hari dan mengoptimalkan layanan yang diberikan oleh perangkat masjid. Aplikasi berbasis Android ini nantinya akan menjadi alat digital dalam menerima donasi untuk pelaporan zakat, infaq dan sedekah (ZIS). Penelitian ini juga bertujuan untuk menganalisis dan mengkaji secara deskriptif manajemen masjid Bank Muamalat yang meraih penghargaan "The Best Social Marketing" yang ditinjau melalui teori Public Relations. Metode penelitian yang akan digunakan adalah pendekatan kualitatif. Selain itu, peneliti memilih metode dengan studi dokumen agar data yang diambil sesuai dengan kenyataan yang ada. Hasil dari penelitian ini adalah pelatihan manajemen Masjid Bank Muamalat telah mencoba memanfaatkan teknologi melalui pelatihan-pelatihan yang diadakan oleh Bank Muamalat sendiri bekerjasama dengan Badan Amil Zakat Nasional (BAZNAS) untuk melatih manajemen masjid agar berkembang di era digital seperti sekarang ini.
\end{abstract}

Kata Kunci: Mualat, Manajemen Masjid, Pelatihan, Teori Public Relations 


\section{INTRODUCTION}

The development of Information and Communication Technology makes it easier for humans to carry out daily activities. Every element of society can certainly move to create a better human life. It is also certainly taken by many people, groups and even a corporation, one of which is Bank Muamalat. The company engaged in banking helps mosques around the islands of Java and Sumatra in carrying out their duties to serve worshipers in performing zakat, infaq, almsgiving and waqf.

PT. Bank Muamalat Indonesia Tbk ("Bank Muamalat Indonesia") first initiated its business trip as the first Sharia Bank in Indonesia on November 1, 1991 or 24 Rabi'us Tsani $1412 \mathrm{H}$. The establishment of Bank Muamalat Indonesia was also initiated by the Indonesian Ulema Council (MUI), the Indonesian Muslim Scholars Association (ICMI) and Muslim businessmen who later received support from the Government of the Republic of Indonesia. (bankmuamalat.co.id, access August 28, 2021). Since officially operating on May 1, 1992 or 27 Shawwal 1412 H, Bank Muamalat Indonesia continues to innovate and issue Sharia financial products such as Sharia Insurance (Takaful Insurance), Muamalat Financial Institution Pension Fund (DPLK Muamalat) and sharia multifinance (Al-Ijarah Indonesia Finance) which are all breakthroughs in Indonesia. In addition, the Bank's Shar-e product launched in 2004 is also the first instant savings in Indonesia. Shar-e Gold Debit Visa product launched in 2011 was awarded by the Indonesian Record Museum (MURI) as the first Sharia Debit Card with chip technology in Indonesia as well as e-channel services such as internet banking, mobile banking, ATM, and cash management. All these products became pioneers of Shariah products in Indonesia and became an important milestone in the Islamic banking industry.

Bank Muamalat is also active in forming a coaching program and activities that are positive, one example of its coaching program activities is the training of muamalat mosque management. This program is followed by 300-500 people from each region. These cities include Jogjakarta, Tegal, Pekalongan, Purwokerto, Medan, Sragen, Solo, and many more. In the training, people are invited to practice using new platforms and media to facilitate their daily activities and work. It is reported that (Marketing Mix Award, mix.co.id, access August 21, 2021) that Bank Muamalat created an application called Smart-Masjid to facilitate the operation of daily mosque management and optimize the services provided by mosque devices. This Android-based application will later become a digital tool in receiving donations for zakat, infaq and alms (ZIS) reporting (Prosperous Mosques in the Digital Era Ala Bank Muamalat, bankmuamalat.co.id, access September 4, 2021). Smart Masjid has been implemented by several mosques in Indonesia. Besides that, Smart Masjid can be used to campaign for the programs of each Mosque. The administration can be connected directly starting from submiting mosque construction funds, receiving mosque funds, and reporting used masque funds. Management can be monitor in a realtime and connected directly to the online banking through the Mosque account number. With the mobile Smart Masjid, it is expected to make it easier for worshipers to make payments without having to go to the Mosque so that they can make payments on time. 
Before that, of course Bank Muamalat has conducted training on mosque members to master existing applications. This is done so that existing human resources are increasing in quality so that the technology supports. Of course, what is done by Bank Muamalat is one step to fulfill the obligation to help the community, this can also be referred to as corporate social responsibility or CSR. Corporate Social Responsibility (CSR) itself is one of the innovative instruments that can help companies to be sensitive and adaptive to the environment and people's lives (Wahyuningrum, 2015). Therefore, one of the important agendas is how to prioritize environmental issues and sustainable development into the implementation of corporate CSR, with the establishment of synergies and good partnerships between companies, NGOs, local governments, and other community groups, so as to contribute to environmental protection and management efforts. But in practice it is still quite difficult to distinguish between Corporate Social Responbility (CSR) and actions that are mere imagery, therefore some of these things must be reviewed and reviewed more deeply.

Along with the development of corporate awareness of the importance of relationships with the community, the concept of Corporate Social Responsibility (hereinafter written with CSR) develops. Corporate Social Responsibility is "An action or concept carried out by a company (according to the company's capabilities) as a form of their responsibility to the social or environmental environment around the company" (Rachman et al, 2016: 16). Companies that put forward this concept will emphasize social development and community capacity building so that it will explore the potential of local communities that become the company's social capital to progress and develop, and later it is expected that companies will still understand their responsibility to the surrounding environment (Busyra. 2011). Benefits of Corporate that implemented CSR, that impact for the company, then by itself the company has carried out social investments (Herman, 2019).

Therefore, researchers want to review and evaluate Bank Muamalat's mosque management training program using Stakeholder Theory. Stakeholder theory explains which party the company is responsible for. The Company must maintain relationships with its stakeholders by accommodating the wants and needs of its stakeholders (Mukarom, 2015), especially those who have power over the availability of resources used for the company's operational activities, labor operations, market for company products and others. Management plan for a mosque needs a careful planning. If the plan cannot run well, so the financial or management plan for mosque will be missunderstand each other. With the marketing plan that can encourage each individual to be able to analyze the situation of the consumer's situation so that it can increase the drive in measuring the index of management results or the ability to deal with changes in marketing (Suciati, 2017). Of course, this can also make a measure of the success of the management program that has been done. The Mosque can prepare various summaries of the plan to be carried out in the appropriate management situation in a financial sense that is suitable for the Mosque itself.

The development of Stakeholder theory begins with the change in the form of the company's approach in conducting business activities. According to Mardikanto 
explanation there are two forms in the stakeholder approach, namely old-corporate and new-corporate relations (Mardikanto, 2014). Old-corporate relations emphasize the form of implementation of corporate activities that each function performs its own work without any connection with other functions. So this also makes the relationship between the company leader and employees only run in one direction and seem rigid. This makes the company run in the interests of their respective leaders seems incompetent because sometimes the activities carried out by them are different from the vision and mission of the company. Later there will be an analysis with the aim of informing about what tactical steps are appropriate in order to help develop the objectives of the financial management of the Mosque. Management strategies carried out must also be proclaimed in appropriate and effective programs in supporting the program. Budget is also the main point that must be determined so that the implementation deadline can be associated with each other. In addition, supporting documents are also a reference or component in conducting financial evaluation research that is very decisive for the company in the future.

If the implementation happens, then the relationship built with outsiders is only limited to transactional relationships. So old-corporate relations is considered to cause a lot of problems because the company leaders seem to keep their distance from the public both internally and externally. New-corporate relations emphasizes collaboration between the company and all its stakeholders so that the company does not just place itself as a part that works alone in the social system of society because professionalism has become the main thing in this pattern of relationships. In this new-corporate relationship, the distance between company leaders and company employees is dwindling. Similarly, the external public relations, not only limited to transactional relationships but the existence of internal public is also used to improve the company's image even better.

These CSR and Stakeholder Theory put society first in the activities that carried out on the future. A company must have an active role in social life, because of course a company cannot move on its own without the support of the surrounding community. This is evidenced by Bank Muamalat by conducting Mosque Management Training activities. This activity aims to create a good image by making Bank Muamalat as a representation to help the social life of a good society. In addition, the hope is that after reviewing and analyzing the program from Bank Muamalat we can add insight, information, and facts on the ground in the field of communication science and can also provide information about the importance of running customer social responsibility programs to the public.

Understanding CSR can actually be viewed from various perspectives. According to (Johnson and Johnson, 2006: 112) CSR is defined as "Corporate Social Responsibility (CSR) is about how companies manage the business processes to produce an overall positive impact on society". What that means is Corporate Social Responsibility (CSR) that is how companies manage business processes to produce an overall positive impact on society. Another view according to (Edi Suharto, 2008: 3), he stated that corporate social alignment with society contains motives, both social and economic. CSR has benefits (consequences) both socially and economically. Social costs incurred by 
companies have the benefit of improving social performance, namely increasing legitimacy and reducing stakeholder complaints.

CSR's relationship is tantamount to fostering good relations with corporate and public stakeholders. Fostering relationships with the public certainly requires the right foundation for the creation of the goals demanded by the company, one of which is to have a deep understanding of the stakeholder context. There is a public relations theory that discusses it, and the theory is called stakeholder theory. Stakeholder theory was developed by Edward Freeman which describes the process of building relationships that organizations have with the actors around them related to the day-to-day operations of the organization. Freeman defines stakeholder relations as a group or individual who can influence and/or be influenced by the achievement of a particular goal (Freeman, 2009). And then the correlation between CSR and stakeholders is rooted in the management of partisanship (legitimacy) of things. It should be considered as the foundation of a system to prioritize partisanship to the society, the company's operations must be related to community expectations. Legitimacy theory also encourages companies to ensure that their activities and performance are acceptable to the public. Companies use their annual reports to illustrate the impression of environmental responsibility, so that they are accepted by the community.

\section{METHODS}

In this study, researchers decided to conduct research with a qualitative approach, Qualitative is also usually referred to as naturalistic research methods which means the research carried out is in accordance with the conditions that are happening in the field. This research is done without making things up or regulating anything, so this research must be made naturally (Sugiarto, 2015: 8). The analytical method used is a descriptive qualitative analysis method. According to Bogdan and Taylor: "Qualitative methodology is a research procedure that produces descriptive data in the form of written or oral words from people or observed behaviors. His approach is directed at the background and the individual holistically." (Moleong, 2013). Researchers use qualitative methods because they want to be involved in their activities, as stated above, "relying on observing humans in their own territory and relating to those people in their language and in their events". Descriptive methods aim to systematically describe the facts or characteristics of a particular population or field found factually and carefully (Rakhmat, 2013).

Of course, qualitative approach takes a targeted data collection method so that the expected data in accordance with the purpose of this research is made. Researchers choose a method with document studies so that the data taken is in accordance with existing reality. Document Studies is one of the ways researchers get data written or made by the subject concerned (Sugiyono, 2016). So with the research method that has been selected, the hope is that this research can answer the questions and problems that are happening on this topic. Assessment analysis using CSR theory, stakeholder theory and theory legitimization becomes a strong foundation that refers to the comprehensive classification of understanding. 


\section{RESULTS}

\section{Smart Mosque Application by Bank Muamalat}

PT. Bank Muamalat Indonesia Tbk. (Bank Muamalat) developed a donation acceptance application for mosques in an effort to develop digitalization. In the current digital era, Bank Muamalat also introduced the Smart-Masjid application as a digital means of receiving zakat, infaq, alms, and waqf reporting donations. This Android-based application will later become a digital tool that is useful to serve the payment of a number of bills, including electricity, water, BPJS Health and Employment, and taxes through the application. Besides that, there's Qibla direction and prayer schedule. According to The Chief Executive Officer (CEO) of Bank Muamalat, Achmad K. Permana, this application was designed with the aim of converting mosques in the digital era as a digital means in receiving zakat, infaq, alms (ZIS) reporting donations. Applications play an important role in the business of a bank in the digital era, therefore this application is deliberately made user-friendly to be easily used by the public. Mobile banking Bank Muamalat is part of an integrated application called Muamalat Mobile.

Not only as a digital means for receiving zakat, infaq, alms (ZIS) reporting donations, the application also includes virtual account features, Internet Banking access, ATM and branch location info, qibla directions and prayer schedules. The use of applications or software in the field of finance is certainly very helpful for all elements of society. There are various benefits obtained, one of which is effectiveness in conducting economic activities and financial calculations. The most important advantage of using applications in this area of finance is that the manager of the Mosque can save a lot of time and energy rather than using manual (traditional) bookkeeping. With computerized financial applications, recording business documents at the beginning to the end and recording transactions to the mosque management can be done simultaneously. In the traditional financial work system, all records of general transactions and adjustments of financial funds will be processed into financial statements towards the end of the year. The purpose of this is for performance assessment, audit needs, and other administrative needs. While in the electronic bookkeeping system through the application, all needs can make all these things like we use our respective fingers. It also allows mosque managers in the area to conduct surveys and evaluations of the implementation of the business financial system at any time so that all financial related problems can be resolved quickly and clearly.

Similar to the management carried out for the Mosque, this marketing relationship can identify the public or stakeholders of the targets prepared. In the future, of course, the preparation focuses on marketing efforts that can create attractive assets or good service handling so that revenue can be shown to a company. Then the Mosque can also do good management management in any aspect including financial aspects. So that it will form a stronger bond of the things that are intended towards the marketing. Individuals can also give each rank by pushing the value proportionally to what is produced from a related institution or corporation. The ability of the institution can also be a core approach in building long-term relationships between institutions and their intended targets.

Then when the managers of the Mosque use a computerized application system, then some errors such as errors in calculating nominal numbers in the mosque book or daily 
writing errors (typo) will be minimized. When the application will process a complex and complex calculation, then automatically the system will calculate it accurately. These advantages are very useful when the manager of the Mosque handles a lot of financial management. Marketing can be said as a function that associates management and organizations in driving a series of processes to create, communicate, and deliver value to the intended consumer. Marketing Management makes the science of the target market can be achieved as a defense in communicating suitable value so as to oversee obtaining a favorable exchange level with the target buyer as a framework for the achievement of organizational goals. Of course later this education process can make marketing as a suitable management step in interpreting each other's interests. It is also important in terms of management to be able to get to know and pay attention to every contribution generated from individuals. What is the reason to be given an appropriate contribution step so that the purpose of good marketing or management relationship activities can be improved or collaborated with other supporting values. Mosques can attract individuals by launching a potential program so that appropriate steps can be aimed at their intended targets. The trust of an institution becomes the right approach in building a relationship of value by adding financial and economic benefits so that finances can be arranged as well as possible without having to change the preferences of the individuals concerned.

The Mosque can also be a place in improving good relations, of course in that it takes a management that can build good relationships without having to distinguish one thing from other things. Waking up in a system by interpreting various knowledge and skills is also an important step in preparing the use of services that are in common with the basic objectives of implementing recommendations from prepared management. It is also important to prepare an appropriate organizational diagram so that management can be arranged as well as possible. This review of PR theory can be rooted in various perspectives, one of which is CSR. This is because CSR as part of the institution's accountability to external stakeholders. So that the results can get a good and appropriate impact in supporting the branding and positioning of the company, especially in a sophisticated and global era, a company that pays attention to the various interests around them. Muamalat in the program they presented with the management of this Mosque is very supportive of areas that do not understand about financial management. 
Flowchart 1 Muamalat Mosque Management Plan for Mix Concept

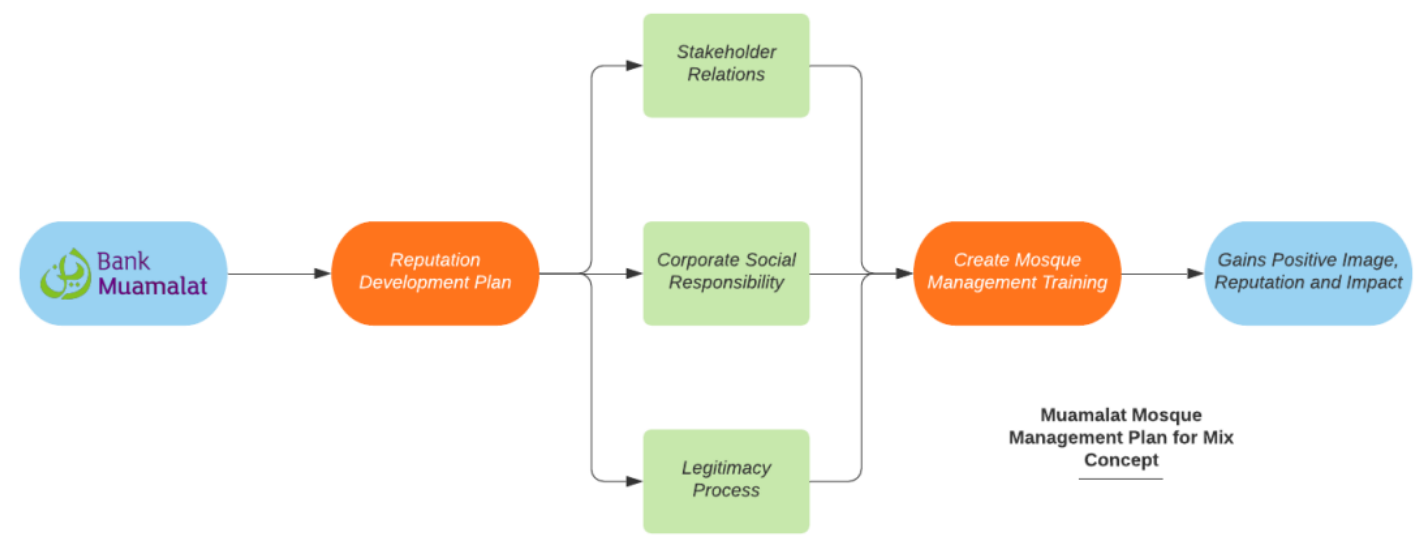

So Muamalat will indirectly get a positive impact because CSR is carried out in line with the company's operational value chain. In the management of CSR must be informed well conveyed so that the targets they aim to understand that this program is an important component in the company in the sense of Muamalat so that it is integrated with the right services in this sense also mosques that have good financial management. Muamalat's connection with mosques that both move to preach something here it appears that Muamalat supports mosque programs and even trains these individuals to be able to manage the finances of mosques with management as effectively as possible. Understanding will increase because CSR Muamalat understands the interests and things needed by the surrounding community it also supports skills in implementing CSR management both strategic planning implementation programs and evaluation in the future. Even CSR from Muamalat can be something that may be applied by various other corporate companies because it has a tremendous positive impact on the stakeholders around them. Stakeholders and public relations become sustainable development so that the company in the sense of Muamalat can carry out functions as well as possible of course this goes through various consultations related to finance before carrying out the implementation so that the goals of Muamalat can be realized, namely providing training and management programs to mosques around Muamalat itself.

\section{Management Training Activities from Bank Muamalat "The Best Social Marketing"}

So this activity is the same as quoted in the MIX Marketing Communication article, in order to present a comprehensive and comprehensive solution to mosque managers to facilitate them in recording mosque finances and zakat collection, infaq, alms (ZIS), and waqf, Bank Muamalat held a mosque management training program. The program was held in a number of cities in Java and Sumatra such as Jogjakarta, Tegal, Pekalongan, Purwokerto, Medan, Sragen, Solo, etc. Each training is attended by about 300-500 participants. Mosque Management Training in Yogyakarta in early April 2018 was followed by the opening of 1,000 Mosque accounts in Central Java. This is the 3rd Mosque Management Training program after success with 300 Mosques in Tegal and 773 Mosques in Pekalongan Regency. In its implementation, Bank Muamalat in collaboration with the National Amil Zakat Agency (BAZNAS) and the Yogyakarta City Mosque Council held a training themed "Magnificent 
Mosque, Jamaah Indah, Dana Melimpah" and invited 400 Takmir chairmen in the city of Yogyakarta.

Following the understanding of Corporate Social Responsibility (CSR), CSR tells the companies to how manage business processes and generate an overall positive impact to the community (Gantino, 2016), Bank Muamalat presents a comprehensive and comprehensive solution to mosque managers to make it easier for them to record mosque finances and zakat collection, infaq, almsgiving, and waqf, Bank Muamalat held a mosque and mosque management training program in collaboration with Bank Muamalat will be a ai muamalat. In accordance with stakeholder theory, stakeholders can be interpreted as individuals, groups, or organizations that are directly or indirectly, potentially or may be related to (influencing or influenced) organizational activities.

It can be seen that mosques that agree to cooperate with Bank Muamalat are part and have an important role for Bank Muamalat. In addition, with the theory of legitimacy that explains that as a system prioritizes partisanship to society, the company's operations must be related to community expectations, with the creation of smart-masjid applications are expected to facilitate the operation of daily mosque management and optimize the services provided by mosque devices and convert mosques in the digital era. So later as a digital means in receiving waqf, zakat, infaq, alms (ZIS) reporting donations that can help serve the payment of a number of bills, including electricity, water, BPJS Health and Employment, and taxes through the application. Bank Muamalat also provides assistance to marbots in the Mosque in the form of BPJS Employment facilities, for one year as a form and impression of environmental responsibility, so that they are accepted by the community.

\section{Study of theory in marketing from Bank Muamalat "The Best Social Marketing"}

Furthermore, the World Business Council and Sustainability Development (WBCSD) explains the notion of corporate social responsibility, it is defined as follows "The continuing commitment by business to behave ethically and contribute to economic development while improving the quality of life of the workforce and their families as well as of the local community and society at large." So the meaning of that explanation is the continued commitment of businesses to behave ethically and contribute to economic development while improving the quality of life of their workforce and families as well as local communities and communities in general is part of corporate social responsibility to the public or its stakeholders (WBCSD Business Association, 2002). These definitions show the diversity in interpreting, understanding, and implementing CSR, so that, until now there is no agreement on the limits of corporate social responsibility to the public.

This linkage is further strengthened because Freeman discusses offering pragmatic approaches to encourage organizations to understand their stakeholders in order to achieve the best conditions or superior-performance. Stakeholders can be defined as individuals, groups, or organizations that are directly or indirectly, potentially or may be related to (influencing or influenced) organizational activities. Grunig \& Repper also explained about Stakeholders (Grunig \& Repper, 2008: 125). Communities are stakeholders because they are in categories that are influenced by organizational decisions or if their decisions affect the organization. Many people in stakeholder categories — such as employees or residents of a 
community - are passive. Stakeholders who become or become more aware and active can be described as public. This theory reminds managers that managers need to pay attention to all people and groups that can influence each other by achieving the goals of the business enterprise. When the application to Bank Muamalat rise quickly, then The public concept in the book written by Rachmat Kriyantono refers to a more specific term than stakeholder, namely a group of people who have the same attention (therefore they are already aware) to an issue and allow to respond with certain behaviors, verbal or non-verbal (Kriyantono, 2014). Stakeholders also differ by type, organization, and the existence of internal positions such as CEO, directors, managers, stockholders and external such as consumers, communities, community groups, governments, banks, media, and so on. Linking with legitimacy, a thorough solid foundation exists on an element of legitimacy that can be perceived as equalizing perceptions or assumptions of changing actions. What must be done by an entity is an action that is desired, appropriate or in accordance with the socially developed system of norms, values, beliefs and definitions (Suchman, 1995 in Kirana, 2009). The rationale of this theory is that the organization or company will continue its existence if the community realizes that the organization operates for a value system commensurate with the value system of society itself, the company itself must convince the public that their activities, activities and reports of activities are so good that in the end all of these things are acceptable to the community.

Therefore, it is important to know the concept of application of mosque management held by Muamalat Bank in line with the principle of combining corporate responsibility with corporate stakeholders. There will be a number of more understandings about stakeholders and the public which is always an important study in public relations practitioners. Muamalat in this sense is important organization to interpret a system as what is needed by public relations in detecting the impact of the relationship between the organization and other subsystems. So that it is possible to get good results from the detection of relationships or corporate programs.

\section{CONCLUSION}

Based on our discussion and understanding, the conclusion of the results of writing this paper is that Bank Muamalat mosque management training has tried to utilize technology through trainings held by Bank Muamalat itself in collaboration with the National Amil Zakat Agency (BAZNAS) to train mosque management in order to develop in the digital era as it is now. The mosque management is trained through a donation acceptance application made by Bank Muamalat, with the aim for upgrading the mosques in the digital era as a digital means in receiving zakat, infaq, alms (ZIS) reporting donations.

Bank Muamalat ultimately put forward a concept that emphasizes social development and community capacity building and supports the potential of local communities that become the social capital of companies to progress and develop, the presence of smart applications and management training also contributes to the development of the community itself. So if we want to associate with public relations theories, the training program and application of Bank Muamalat is one of the programs that support the surrounding community and how Bank Muamalat manages business processes and the pace of this 
company to produce an overall positive impact on the surrounding communities in Java and Sumatera.

Research on selected topics still reveals a small percentage of the problems studied in this article. In this case, of course, a more in-depth study is needed so that it is possible to answer other discussion materials. For this reason, it is recommended to the next researcher who is interested in conducting studies in order to see from perspective and related theories so as to enrich the existing analysis or discussion.

\section{ACKNOWLEDGMENT}

We as a research team would like to express our deepest gratitude to a number of parties who contributed to this study. And we would like to thank you for the support of $\mathrm{Al}$ Azhar University Indonesia (UAI), especially our family, and also colleagues who always support and provide input for us. Including those whose work was cited in this study.

\section{REFERENCES}

\section{Journal}

Gantino, Rilla. 2016. Pengaruh Corporate Social Responsibility Terhadap Kinerja Keuangan Perusahaan Manufaktur yang Terdaftar di Bursa Efek Indonesia periode 2008-2014. Jurnal Dinamika Akuntansi dan Bisnis Vol. 3(2), 2016. Jakarta: Univ Esa Unggul.

Herman. 2019. Manfaat Corporate Social Responsibility oleh Stakeholder. Jurnal Ilmiah Manajemen Publik dan Kebijakan Sosial. Vol. 2 No. 2 Tahun 2018.

Igi Global. 2021. Corporate Social Responsibility. IGI Journal www.igi-global.com/dictionary/CSR. Accessed on 10 September 2021, times 13.01 WIB.

Kirana, Rosita Chandra. 2009. Studi Perbandingan Pengaturan tentang CSR di Beberapa Negara dalam Upaya Perwujudan Prinsip Good Corporate Governance. Research on Universitas Sebelas Maret Surakarta.

Wahyuningrum, Yuniarti. 2015. Pengaruh Program Corporate Social Responsibility Terhadap Penigkatan Pemberdayaan Masyarakat (Studi pada Implementasi CSR PT. Amerta Indah Otsuka Desa Pacarkeling Kecamatan Kejayan Kabupaten Pasuruan). Jurnal Administrasi Publik (JAP), Vol.1 No.5, Malang: Universitas Brawijaya.

\section{Article}

Pelatihan Manajemen dari Bank Muamalat "The Best Social Marketing. 2018. https://mix.co.id/mixaward/pelatihan-manajemen-masjid-bank-muamalat-the-best-social-marketing/. Mix.co.id. Accessed on 20 August 2021, times 12.30 WIB.

Muamalat. 2018. https://www.bankmuamalat.co.id/profil-bank-muamalat. Acsessed on 09 September 2021, times 13.13 WIB.

\section{Books}

Busyra, Azheri. 2011. Corporate Social Responsibility: Dari Voluntary Menjadi Mandatory. Jakarta. PT Raja Grafindo Persada.

Freeman, R. Edward. 2009. Stakeholder Capitalism. Journal of Business Ethics. University of Virginia - Darden School of Business.

Grunig, James E. 2008. Excellence in Public Relations and Communications Management. Routledge: Lawrence Erlbaum Associates, Inc.

Kriyantono, Rachmat. 2014. Teori Public Relations: Perspektif Barat \& Lokal (Aplikasi Penelitian dan Praktik). Jakarta: Kencana. 
Mardikanto, Totok. 2014. CSR Corporate Social Responsibility. Bandung: Alfabeta.

Mukarom, Zainal \& Laksana, Muhibudin Wijaya. 2015. Manajemen Public Relations (Panduan Efektif Pengelolaan Hubungan Masyarakat). Bandung: Pustaka Setia.

Moleong, Lexy J. 2013. Metodologi Penelitian Kualitatif Edisi Revisi. Bandung: PT. Remaja Rosdakarya.

Rachman, Nurdizal M, dkk. 2011. Panduan Lengkap Perencanaan CSR. Jakarta: Penebar Swadaya.

Rakhmat, Jalaluddin, 2013. Psikologi Komunikasi. Bandung: PT Remaja Rosdakarya.

Suciati. 2017. Teori Komunikasi Dalam Multi Perspektif. Yogyakarta: Buku Litera.

Sugiarto, Eko. 2015. Menyusun Proposal Penelitian Kualitatif Skripsi dan Tesis. Yogyakarta: Suaka Media.

Sugiyono. 2016. Metode Penelitian kuantitatif kualitatif dan R\&D. Bandung: Alfabeta.

Wahyudi, Isa dan Busyra Azheri. 2011. Corporate Social Responsibility: Prinsip, Pengaturan dan Implementasi, Malang: In-Trans Publishing.

WBCSD. 2002. Corporate Social Responsibility. The WBCSD's Journey. WBCS. 